\title{
'Bonita' Sweetpotato
}

\author{
Don R. La Bonte ${ }^{1}$ \\ Louisiana Agricultural Experiment Station, Louisiana State University
} Agricultural Center, School of Plant, Environmental, and Soil Sciences, 104 Sturgis Hall, Baton Rouge, LA 70803

\section{Christopher A. Clark \\ Department of Plant Pathology and Crop Physiology, Louisiana State University Agricultural Center, 302 Life Sciences Building, Baton Rouge, LA 70803}

\section{Tara P. Smith and Arthur Q. Villordon \\ Sweet Potato Research Station, Louisiana State University Agricultural Center, P.O. Box 120, Chase, LA 71324}

Additional index words. vegetable breeding, disease resistance, cultivar

'Bonita' sweetpotato [Ipomoea batatas (L.) Lam.] was developed by the Louisiana Agricultural Experiment Station to provide a specialty-type white-fleshed, tan-skinned cultivar similar to 'O'Henry' but with southern root-knot nematode and soil rot resistance, superior storage root shape, and a higher dry matter content. 'Bonita' produces excellent numbers of uniform plants (sprouts) early in the production season. Days to harvest for 'Bonita', 'Beauregard' (Rolston et al., 1987), and 'O'Henry' are similar in the Gulf South production region; 'Bonita' in North Carolina is later by 7 days. The roots are elliptical and consistent in shape in varied soil types. Yields are equal to and mostly superior to 'O'Henry' for the U.S. \#1 grade (5.1 to $8.9 \mathrm{~cm}$ diameter, 7.6 to $22.9 \mathrm{~cm}$ long) in Louisiana and other Gulf southern states. 'O'Henry' is a whitefleshed, tan-skinned mutation of 'Beauregard' that was found and became commercially grown in the late 1990s.

Initially identified and evaluated as L0529 , the cultivar is named after the town of Bonita, LA, located in a major sweetpotato production region. The name is also a reflection of its consistent and attractive root shape.

\section{Origin}

'Bonita' originated in 2005 as a seedling from an open-pollinated polycross nursery of

\footnotetext{
Received for publication 3 Feb. 2011. Accepted for publication 8 Apr. 2011.

Supported by state and matching funds allocated to the Louisiana State University Agricultural Center and the Louisiana Sweet Potato Advertising and Development Commission.

Approved for publication by the Director of the Louisiana Agricultural Experiment Station as manuscript number 2011-306-5430.

We appreciate the assistance of Dr. Ramon Arancibia, Mississippi State University-MAFES, Ponotoc Research Station, Ponotoc, MS, and Mr. Arnold Caylor, North Alabama Horticulture Research Station, Cullman, AL, with research plots.

${ }^{1}$ To whom reprint requests should be addressed; e-maildlabonte@agcenter.lsu.edu.
}

the previous year. The female lineage is 'Excel', originally tested as W-221 (Jones et al., 1989). 'Regal', originally tested as W-152 (Jones et al., 1989), is the female parent of 'Excel'.

\section{Description}

'Bonita' has green-stemmed vines corresponding to color charts as $2.5 \mathrm{G}$ (green) $\mathrm{Y}$ (yellow) (6/6) (Munsell® Color, New Windsor, NY) from the apex and then transitions to a dark maroon [5 R (red) (3/2)] on older parts of the vines near the crown of the roots. The 'Bonita' canopy biomass appears to be greater than that for 'O'Henry', a white-fleshed mutation of the 'Beauregard' cultivar. Unfolded immature leaves are green $[2.5 \mathrm{G}$ (green) $\mathrm{Y}$ (yellow) (5/4)] for the upper and lower surface and change over one to two nodes to a darker green upper [7.5 G (green) Y (yellow) (3/4)] and lower [5 G (green) Y (yellow) (4/6)] surface. Mature leaves at five nodes from the apex are glabrous, have an acute apex, and mostly a cordate base and a smooth leaf margin. Mature leaves are similar in size to that of 'Beauregard' or 'O'Henry'.

A typical inflorescence of 'Bonita' has three flowers per peduncle. Individual flowers are $\approx 4 \mathrm{~cm}$ long from the base of the calyx, and the corolla is $3 \mathrm{~cm}$ wide at the opening. The flower is mostly light purple [5 P (purple) $(9 / 2)]$ on the exterior and darker in the throat of the corolla [2.5 R (red) P (purple) (3/8)]. Stigmata appear purple [7.5 R (red) P (purple) $(7 / 8)$ ]. Four of the five stamens are inferior to stigmata and attached to the ovary; one is slightly superior. Storage roots are elliptical without lobing and consistent in shape. Skin is light tan [10Y (yellow) R (red) 8/6] with a pink cast at harvest. This is considered a negative trait; however, the pink cast fades in storage (<http://www.lsuagcenter.com/en/our_offices/ research_stations/Sweetpotato/Features/varieties/ index.htm $>$ ). 'O'Henry' has grooving along the length of the root, more prominent lenticels, and a greater length. Some root veining on 'Bonita' is noticed in California (NSPCG, 2011). The 'Bonita' cortex is 4 to $5 \mathrm{~mm}$ in depth. The flesh of 'Bonita' is white with a yellow cast [7.5 Y (yellow) 9/4] in comparison with 'O'Henry', which has an orange cast [5 Y (yellow) 9/4]. Dry matter content is $\approx 29 \%$ for 'Bonita' in comparison with 'O'Henry' at $\approx 25 \%$.

\section{Disease Reactions}

'Bonita' was compared with 'Beauregard' in controlled tests. 'O'Henry' has not been tested but is assumed to react similarly to that of 'Beauregard'. It is intermediate or slightly less resistant than 'Beauregard' for soil rot caused by Streptomyces ipomoeae (Person \& W.J. Martin) Waksman \& Henrici. This level of resistance is meaningful from a production standpoint. 'Bonita' is slightly less resistant than 'Beauregard' to fusarium wilt or stem rot caused by Fusarium oxysporum Schlect. f. sp. batatas (Wollenw.) Snyd. \& Hans. 'Bonita' is highly resistant in greenhouse evaluations to race 3 of southern root-knot nematode, Meloidogyne incognita (Kofoid \& White 1919) Chitwood 1949; resistance is greater than for highly susceptible 'Beauregard'. It was rated as resistant in 2010 National Sweetpotato Collaborators Pathology Trials conducted by J.A. Thies and D.M. Jackson (USDA Vegetable Laboratory, USDA, ARS, Charleston, SC). It is susceptible to intermediate to fusarium root rot caused by Fusarium solani (Sacc.) Mart. emend. Snyd. \& Hans.; 'Beauregard' is resistant. Similar to 'Beauregard', storage roots of 'Bonita' are susceptible to bacterial soft rot caused by Erwinia chrysanthemi Burkholder, McFadden \& Dimock. Reaction to viruses has not been determined.

Insect resistance. 'Bonita' is currently under trial for relative insect resistance, but it has not demonstrated any unusual propensity to insect damage in numerous on-farm trials.

\section{Production}

'Bonita' was compared with 'O'Henry' and 'Beauregard' in randomized complete block trials with three or four replications at various locations in Louisiana, Arkansas, and Alabama. There were two to five trials each year over a 4-year period (2007 to 2010). These covered a wide range of planting dates and growing days. 'Bonita' produced yields comparable to and exceeding 'O'Henry' in regional trials at various planting dates (Table 1). Yield in sandy loam soils (Montrose, AR; Elberta, AL; Bonita, LA) showed 'Bonita' had a higher yield of U.S. \# 1 grade in comparison with 'O'Henry', whereas yield in silt loam soils (Wisner, LA) were more comparable (Table 1). Replicated plots at other farms and on station have shown 'Bonita' has consistent yields for early-, middle-, or late-season plantings. Yield declines are within norms in poor environments. 'Bonita' had harvestable roots $\approx 110$ to $115 \mathrm{~d}$ after planting, which is typical development time for sweetpotatoes and comparable to 'O'Henry'. The yield of Jumbo grade (larger than U.S. \#1 in diameter or length or both and without objectionable defects) is indicative of earliness and 'Bonita' 
Table 1. Yield by grade of 'Bonita' in replicated trials.

\begin{tabular}{|c|c|c|c|c|c|}
\hline \multirow[b]{2}{*}{ Cultivar } & \multirow[b]{2}{*}{ U.S. \# 1} & \multicolumn{4}{|c|}{ Avg yield $\left(\mathrm{Mt} \cdot \mathrm{ha}^{-1}\right)^{\mathrm{z}}$} \\
\hline & & Medium & & Jumbo & Total marketable \\
\hline & & & $\begin{array}{c}2008 \\
\text { Wisner, LA, midseason }\end{array}$ & & \\
\hline Bonita $^{y}$ & $22.7 \mathrm{a}$ & $8.5 \mathrm{a}$ & & $6.6 \mathrm{a}$ & $37.8 \mathrm{a}$ \\
\hline O’Henry & $19.5 \mathrm{a}$ & $9.6 \mathrm{a}$ & & $0.8 \mathrm{a}$ & $29.9 \mathrm{a}$ \\
\hline & & & $\begin{array}{c}2009 \\
\text { Foley, AL, early season }\end{array}$ & & \\
\hline Bonita & $28.3 \mathrm{a}$ & $13.6 \mathrm{a}$ & & $1.6 \mathrm{a}$ & $43.4 \mathrm{a}$ \\
\hline O’Henry & $16.4 \mathrm{a}$ & $16.4 \mathrm{a}$ & & $1.2 \mathrm{a}$ & $31.0 \mathrm{~b}$ \\
\hline & & & $\begin{array}{c}2009 \\
\text { Bonita, LA, late season }\end{array}$ & & \\
\hline Bonita & $26.7 \mathrm{a}$ & $17.8 \mathrm{a}$ & & $0 \mathrm{a}$ & $44.5 \mathrm{a}$ \\
\hline O’Henry & $18.3 \mathrm{~b}$ & $19.8 \mathrm{a}$ & $\begin{array}{c}2009 \\
\text { Vardaman } \text { MS midseason }\end{array}$ & $0 \mathrm{a}$ & $38.1 \mathrm{a}$ \\
\hline $\begin{array}{l}\text { Bonita } \\
\text { O’Henry }\end{array}$ & $\begin{array}{l}19.4 \mathrm{a} \\
19.3 \mathrm{a}\end{array}$ & $\begin{array}{l}21.6 \mathrm{a} \\
15.7 \mathrm{a}\end{array}$ & & $\begin{array}{l}1.8 \mathrm{a} \\
3.0 \mathrm{a}\end{array}$ & $\begin{array}{l}50.3 \mathrm{a} \\
40.4 \mathrm{~b}\end{array}$ \\
\hline & & & $\begin{array}{c}2010 \\
\text { Elberta, AL, early season }\end{array}$ & & \\
\hline Bonita & $7.8 \mathrm{a}$ & $4.2 \mathrm{a}$ & & $0 \mathrm{a}$ & $12.0 \mathrm{a}$ \\
\hline O’Henry & $5.5 \mathrm{a}$ & $6.2 \mathrm{a}$ & $\begin{array}{c}2010 \\
\text { Montrose, AR, midseason }\end{array}$ & $0 \mathrm{a}$ & $11.6 \mathrm{a}$ \\
\hline $\begin{array}{l}\text { Bonita } \\
\text { O’Henry }\end{array}$ & $\begin{array}{r}24.3 \mathrm{a} \\
7.6 \mathrm{~b}\end{array}$ & $\begin{array}{r}6.3 \mathrm{a} \\
10.8 \mathrm{a} \\
\end{array}$ & & $\begin{array}{l}4.0 \mathrm{a} \\
0.2 \mathrm{a}\end{array}$ & $\begin{array}{l}34.7 \mathrm{a} \\
19.3 \mathrm{~b}\end{array}$ \\
\hline
\end{tabular}

z'sizes of roots: U.S. \#1: 5.1 to $8.9 \mathrm{~cm}$ diameter, 7.6 to $22.9 \mathrm{~cm}$ long; medium (canner): 2.5 to $5.1 \mathrm{~cm}$ diameter, 5.1 to $17.8 \mathrm{~cm}$ long; jumbo: larger than U.S. \#1 in diameter or length or both, and without objectionable defects.

yEarly-season plantings (through 15 May), midseason plantings (16 May to 15 June), late-season plantings (16 June through July).

might produce more jumbo roots under ideal conditions. White-fleshed jumbo roots have a low economic value, and therefore management strategies should be taken to limit oversize roots. Root production was also evaluated in numerous locations throughout the United States in the National Sweet Potato Collaborator trials in 2009 and 2010. Yield of 'Bonita' for U.S. \#1 grade exceeded 'O'Henry' by over $10 \%$ in 2009 in two trials in North Carolina, the largest U.S. production region for sweetpotato. In California, U.S. \#1 yield and total marketable yield were statistically similar between 'Bonita' and 'O'Henry' in both years; a high percentage of jumbos was also noted. Yield in nine other plots in Louisiana in years 2006, 2007, and 2008 showed no significant difference in yield in comparison with the high-yielding 'Beauregard' cultivar. Yield of 'Bonita' was significantly higher in one plot in 2007 in comparison with 'Beauregard'. In total, these data reflect consistent high-yield characteristics for 'Bonita'. Plants of 'Bonita' from propagation beds are early and prolific in comparison with 'Beauregard'. No differences in storage quality are noted in comparison with 'O'Henry' or 'Beauregard'; roots are sound and marketable after 6 to 7 months of storage.

Quality attributes. White-fleshed 'Bonita' has excellent culinary characteristics. Sugar profiles for baked 'Bonita' and 'O'Henry' differ for 5-month-old stored roots baked at $190{ }^{\circ} \mathrm{C}$ for $\approx 2 \mathrm{~h}$. Sucrose content in baked 'Bonita' $\left(2.9 \mathrm{mg} \cdot \mathrm{g}^{-1}\right)$ on a fresh weight basis (fwb) was twice that found in baked 'O'Henry' (1.3 mg.g ${ }^{-1}$ fwb). 'Bonita' and 'O'Henry' had similar maltose content $\left(\approx 8 \mathrm{mg} \cdot \mathrm{g}^{-1} \mathrm{fwb}\right)$. Total sugar content was slightly higher for 'Bonita' in comparison with 'O'Henry'. 'Bonita' requires similar baking time in comparison with major dessert-type cultivars.

A high dry matter of $\approx 29 \%$ makes for a drier, flaky texture in comparison with 'O'Henry' at $\approx 25 \%$. 'Beauregard' has a dry matter content of $21 \%$ to $22 \%$. The texture and not the sugar content is the major differentiating feature of 'Bonita'.

\section{Availability}

Limited quantities of foundation seed stock will be commercially available for the 2011 crop season. Requests for roots should be made to the Sweet Potato Research Station, P.O. Box 120, Chase, LA 71324. Intellectual property protection will be sought.

\section{Literature Cited}

Jones, A., P.D. Dukes, J.M. Schalk, and M.G. Hamilton. 1989. 'Excel' sweet potato. HortScience 24:171-172.

Jones, A., P.D. Dukes, J.M. Schalk, M.G. Hamilton, M.A. Mullen, R.A. Baumgardner, D.R. Paterson, and T.E. Boswell. 1985. 'Regal' sweet potato. HortScience 20:781-782.

Rolston, L.H., C.A. Clark, J.M. Cannon, W.M. Randle, E.G. Riley, P.W. Wilson, and M.L. Robbins. 1987. 'Beauregard' sweet potato. HortScience 22:1338-1339. 